\title{
PULSE WAVE VELOCITY AND ITS USEFULNESS IN THE ESTIMATION OF HYPERTENSION
}

\author{
JAYANTHI T, ANBURAJAN M
}

Department of Biomedical Engineering, SRM University, Chennai, Tamil Nadu, India. Email: Jayanthi.t@ktr.srmuniv.ac.in

Received: 05 December 2016, Revised and Accepted: 24 January 2017

\begin{abstract}
Objective: "Arterial vessel wall stiffness" is an important determinant of cardiovascular disease (CVD). Prolonged hypertension causes deterioration in the blood vessel elasticity. Hypertension can be prevented by early diagnosis. Pulse wave velocity (PWV) is the direct method for assessing the arterial stiffness. Though numerous studies have been performed, the definite limit is not declared to evaluate CVD based on the threshold of PWV for South Indian population.
\end{abstract}

Methods: In this study, we included a total of 246 healthy controls and 14 hypertensive patients. Mechanical variables of blood flow are measured using PC-based periScope Device (Genesis Medical Systems, India). The following variables are measured from the normal controls and hypertensive patients: (i) Heart rate (bpm), (ii) systolic blood pressure (SBP) (mmHg), (iii) diastolic blood pressure (DBP) (mmHg), (iv) brachial PWV (baPWV) (cm/s), (v) carotid-femoral PWV (C-F PWV) (cm/s), (vi) pulse pressure (mm Hg), (vii) arterial stiffness index (ASI) (mmHg), (viii) anklebrachial index (ABI), (ix) aortic SBP and DBP (mmHg), and (x) aortic augmentation pressure (mmHg).

Results: The study shows the deterioration in the vessel elasticity with advancing age in both men and women. In the normal men population studied $(\mathrm{n}=135)$, an increase in SBP from a young age to older age was 3.7\%, likewise in women ( $\mathrm{n}=111)$, it was $12 \%$. A standard cutoff value of $1738 \mathrm{~cm} / \mathrm{s}$ for baPWV and $1215 \mathrm{~cm} / \mathrm{s}$ for C-F PWV was calculated from the combined group of known hypertensive patients and age- and sex-matched normal controls.

Conclusion: Thus, the PWV and the variables derived from it can be used for evaluating the status of blood vessels noninvasively.

Keywords: Vascular stiffness, Pulse wave velocity, Gender, Carotid-femoral, Hypertensive.

(C) 2017 The Authors. Published by Innovare Academic Sciences Pvt Ltd. This is an open access article under the CC BY license (http://creativecommons. org/licenses/by/4. 0/) DOI: http://dx.doi.org/10.22159/ajpcr.2017.v10i4.16447

\section{INTRODUCTION}

Hypertension is related to the risk of development of stroke and coronary disease. Many pharmacoeconomic studies reveal an enormous expenditure involved in the treatment of high blood pressure [1]. Hence, an efficient diagnostic method for hypertension is the need of the hour. Reduced compliance or the vasculature distensibility leads to arterial stiffness which is the leading cause of high blood pressure. Pulse wave velocity (PWV) is the measure of arterial stiffness. Arterial wall stiffness is mainly dependent on the blood pressure and the blood cholesterol level. Before the onset of atherosclerosis, there is a significant stiffening of the arteries due to the deposition of small fatty lipids. PWV is the direct method for assessing the arterial stiffness, whereas the augmentation index is the indirect way to evaluate the same. The augmentation index is the measurement of the effect of stiffness on the aorta. Thus, the measurement of the arterial stiffness index (ASI) and augmentation index gives an estimation of the central blood pressure, which is a measure of the patient's arterial vascular system [2]. The abnormalities in the vascular system are an indicator of peripheral vascular disease.

The most common method to measure PWV is oscillometric technique, where the velocity of the blood is calculated from the pressure pulse waveform. It is generated by the ventricular ejection, which travels through the arteries. The graph of this amplitude of the oscillation, measured using the blood pressure cuff in the limbs, is called oscillometric envelope. The distance between the heart and the respective limb divided by the pulse transit time gives the PWV of the own limb. The oscillometric technique provides more relevant and reproducible results [3]. Naidu et al. concluded in their pilot study that the oscillometric periScope device is a simple, non-invasive device with excellent reproducibility [4]. Yashmaina et al. evaluated the patients with arterial stiffness who were at a high risk of cardiovascular disease (CVD). PWV measured from the patients was highly correlated statistically with the standard arterial stiffness parameter, confirming that PWV can be an independent predictor for CVD [5]. The standard variables for the evaluation of end-organ damage are intima-media thickness (IMT) and low estimated glomerular filtration rate according to Matsumoto et al. who postulated that the measured baPWV in hypertensive patients showed the statistically significant difference when compared to the healthy controls [5,6]. Shanker et al. studied the cumulative effects of various biomarkers of atherosclerosis by calculating the PWV, ASI, and AIx in asymptomatic individuals using oscillometric device [3]. Numerous community-based studies have been conducted to evaluate the CVD risk factors using the statistical Tukey's post hoc analysis [6].

Although studies employ the mechanical blood flow variables to examine the hemodynamic properties of the blood vessels, there is no defined threshold for the CVD risk, especially for the South Indian population. Hence, the aim of this study was to collect normative data for mechanical blood flow variables measured using periScope in South Indian men and women and to determine their cutoff value for healthy controls and hypertensive patients. Statistical significance of these variables verified in known hypertensive patients was compared with age- and sex-matched healthy controls.

\section{MATERIALS AND METHODS}

In a private hospital, we organized a free screening camp for hypertensive patients during September 2013. The total number of registered patients of both sexes was 300 , and their age ranged from 18 to 70 years. The institutional Ethical Committee had approved the study (17/IEC/2010). An informed consent form was obtained from 
all patients. A detailed questionnaire prepared for this study was administered to each patient, and the details were noted. Of the total patients enrolled, 40 were known cases of fever, neurological disorders, diabetes mellitus, thyroid abnormalities, and nephropathy, and thus they were excluded from this study. Of the 260 patients, 246 were normal, and the remaining 14 were hypertensive cases. The data were analyzed separately for healthy controls and hypertensive subjects as Study-I and Study-II, respectively. The study groups are as follows:

A. Study-I: It comprised 246 participants, who were normal, i.e., they had no hypertension; their age ranged from 18 to 66 years (mean \pm standard deviation (SD) age $=34.2 \pm 8.7$ years). The participants are classified into two groups as follows:

- Group-I: Normal men ( $\mathrm{n}=135$, mean \pm SD age $=36 \pm 11.33$ years $)$

- Group-II: Normal women ( $\mathrm{n}=111$, mean \pm SD age $=32.4 \pm 7.5$ years).

B. Study-II: It comprised a total of 28 patients, with and without hypertension. The patients are classified into two groups as follows:

- Group-I: Known hypertensive patients $(n=14$, male/ women $=9 / 5$, mean \pm SD age $=39.3 \pm 10.5$ years), average years since hypertension $=2 \pm 0.6$ years

- Group-II: Age- and sex-matched normal controls (n=14, men/ women $=9 / 5$, mean \pm SD age $=39.7 \pm 12.2$ years ).

\section{Methods}

PC-based periScope device (Genesis Medical Systems, India) was used to measure the various mechanical variables of blood flow. The participants were asked to lie in the supine position. After 2-minute resting period, the cuffs are placed on the forearm and legs for measurement of blood pressure. Based on the oscillometric technique, the pressure pulse waveform of the forearm and legs was captured. Simultaneous acquisition of 3-lead electrocardiogram (ECG) was also made. From the ECG and oscillometric envelope, the following variables were measured directly: (i) Heart rate (bpm), (ii) systolic blood pressure (SBP) (mmHg), (iii) diastolic blood pressure (DBP) $(\mathrm{mmHg})$, and (v) pulse pressure ( $\mathrm{mmHg}$ ). In addition, the following variables were derived from the measured pulse pressure waveform: (i) aortic SBP (mmHg), (ii) aortic pulse pressure (mmHg), (iii) aortic DBP (mmHg), (iv) aortic augmentation pressure (mmHg), (v) carotidfemoral PWV (C-F PWV) (cm/s), (vi) BaPWV (bilateral) $(\mathrm{cm} / \mathrm{s})$, (vii) brachial ASI (mm Hg), (viii) ankle ASI (mm Hg), and (ix) anklebrachial index $(\mathrm{ABI})$.

\section{Statistics}

In study-I, both Groups I (healthy men) and II (healthy women) were divided into three tertiles separately based on the patient's age (years) and their corresponding measured SBP (mmHg) using Tukey's post hoc analysis. The Tukey's post hoc analysis determines which tertile in the sample differs significantly based on patient's age and SBP. Independent t-test was carried out to investigate the significance of variables measured between the known hypertensive patients (Group-I) and the normal age- and sex-matched controls (Group-II). All the data were analyzed using IBM SPSS statistical software package version 10.0.

Table 1: Comparison of patient's limb side-specific variation in normal men

\begin{tabular}{|c|c|c|}
\hline \multicolumn{3}{|c|}{$\begin{array}{l}\text { Study-I: Group-I: Normal men }(n=135, \text { mean } \pm S D \\
\text { age }=36.0 \pm 11.3 \text { years })\end{array}$} \\
\hline $\begin{array}{l}\text { Mechanical variables } \\
\text { of blood flow measured } \\
\text { using periScope }\end{array}$ & Left side & Right side \\
\hline \multicolumn{3}{|l|}{ Arm } \\
\hline baPWV (cm/s) & $1307.68 \pm 286.16$ & $1322.03 \pm 282.68$ \\
\hline Brachial ASI mmHg) & $25.52 \pm 6.59$ & $25.8 \pm 8.07$ \\
\hline \multicolumn{3}{|l|}{ Leg } \\
\hline Ankle ASI (mm Hg) & $33.04 \pm 10.41$ & $34.97 \pm 9.04$ \\
\hline \multicolumn{3}{|l|}{ Leg-to-arm pressure ratio } \\
\hline $\mathrm{ABI}$ & $1.1 \pm 0.13$ & $1.15 \pm 0.09$ \\
\hline
\end{tabular}

\section{RESULTS}

Patient's limb side-specific variation

In study-I, the calculated mean \pm SD values of derived mechanical blood flow variables measured on the left and right sides of both upper and lower limbs of both healthy men as well as women studied are listed in Tables 1 and 2, respectively. It was found that, in both healthy men and women, there was no significant statistical difference between the variables mentioned above measured in the left and right sides of the limbs.

\section{Patient's age-specific variation}

Healthy men (Group-I): In healthy men (n=135, mean \pm SD age $=36.0 \pm 11.3$ years), the linear regression analysis showed a statistically significant correlation between age (years) and the mechanical variables of blood flow as shown in Figs. 1-3.

Healthy women (Group-II): In normal women ( $\mathrm{n}=111$, mean \pm SD age $=32.4 \pm 7.5$ years), the linear regression analysis showed a statistically significant correlation between age (years) and variables as illustrated in Figs. 4-6.

\section{Patient's sex-specific variation}

Table 3 provides a comparison of both direct and derived mechanical blood flow variables using periScope between healthy men (Group-I) and women (Group-II). In healthy men (Group-I), the percentage increment was greatest for pulse pressure with $15.7 \%$ $[(57.29-48.31 / 57.29) \times 100]$ Also, in Group-I, in the mean values of all the derived mechanical blood flow variables concerned, the percentage increment was greatest for aortic augmentation pressure with $74 \%$ $[(6.42-1.61 / 6.42) \times 100]$.

\section{Patient's age and SBP variation}

Both Groups I and II (healthy men and women) are subdivided into three tertiles based on the patient's age (years) and their corresponding measured SBP (mmHg) using Tukey's post hoc analysis as shown in Tables 4 and 5.

\section{Healthy men}

The healthy young men (tertile-I) were compared with tertiles II and III as shown in Table 6.

i. With tertile-Il

In middle-aged men (tertile-II), in the mean values of the variables concerned, the calculated percentage decrement was greatest for pulse pressure with $12 \%[(61.21-53.55 / 61.21) \times 100]$, and the estimated percentage increment was highest for C-F PWV with $20 \%[(881.44-730.06 / 730.06) \times 100]$.

ii. With tertile-III

Table 2: Comparison of patient's limb side-specific variation in normal women

\begin{tabular}{lll}
\hline $\begin{array}{l}\text { Study-I: Group II: Normal women }(\mathrm{n}=\mathbf{1 1 1} \text {, mean } \pm \text { SD } \\
\text { age=32.4 } \pm 7.5 \text { years) }\end{array}$ & Right side \\
\hline $\begin{array}{l}\text { Mechanical variables } \\
\text { of blood flow measured } \\
\text { using periScope }\end{array}$ & Left side & \\
\hline Arm & & \\
$\quad$ baPWV (cm/s) & $1044.63 \pm 278.87$ & $1096.2 \pm 206.04$ \\
$\quad$ Brachial ASI (mmHg) & $21.04 \pm 7.2$ & $22.67 \pm 6.52$ \\
$\begin{array}{l}\text { Leg } \\
\text { Ankle ASI (mmHg) } \\
\text { Leg-to-arm pressure ratio } \\
\text { ABI }\end{array}$ & $29.27 \pm 10.01$ & $31.75 \pm 9.05$ \\
\hline
\end{tabular}


Table 3: Comparison between the patient's sex-specific variations with the mean \pm SD values of the mechanical variables of blood flow measured using periScope

\begin{tabular}{|c|c|c|c|}
\hline Variables & $\begin{array}{l}\text { Group I: Normal men }(n=135, \\
\text { mean } \pm S D \text { age }=36.0 \pm 11.3 \text { years })\end{array}$ & $\begin{array}{l}\text { Group II: Normal women ( } \mathrm{n}=111 \text {, } \\
\text { mean } \pm S D \text { age }=32.4 \pm 7.5 \text { years) }\end{array}$ & $\begin{array}{l}\text { Statistical } \\
\text { significance ( } p \text {-value) }\end{array}$ \\
\hline \multicolumn{4}{|l|}{ Demographic variables } \\
\hline Body weight (kg) & $70.58 \pm 12.59$ & $64.3 \pm 12.96$ & $<0.01$ \\
\hline Body height (m) & $1.69 \pm 0.08$ & $1.57 \pm 0.06$ & $<0.01$ \\
\hline $\mathrm{BMI}\left(\mathrm{kg} / \mathrm{m}^{2}\right)$ & $24.83 \pm 4.06$ & $26.08 \pm 5.09$ & $<0.05$ \\
\hline \multicolumn{4}{|l|}{ Mechanical variables of blood } \\
\hline \multicolumn{4}{|l|}{ a. Directly measured } \\
\hline Heart rate (bpm) & $76.86 \pm 12.24$ & $77.56 \pm 9.3$ & NS \\
\hline SBP (mmHg) & $133.56 \pm 16.22$ & $118.48 \pm 13.1$ & $<0.01$ \\
\hline DBP (mmHg) & $76.42 \pm 10.44$ & $70.25 \pm 9.34$ & $<0.01$ \\
\hline Pulse pressure (mmHg) & $57.29 \pm 10.7$ & $48.31 \pm 8.53$ & $<0.01$ \\
\hline \multicolumn{4}{|l|}{ b. Indirectly derived variables } \\
\hline \multicolumn{4}{|l|}{ Derived pressure } \\
\hline Aortic SBP (mmHg) & $113.05 \pm 15.99$ & $96.73 \pm 13.32$ & $<0.01$ \\
\hline Aortic pulse pressure (mmHg) & $36.5 \pm 8.58$ & $26.98 \pm 7.69$ & $<0.01$ \\
\hline Aortic DBP (mmHg) & $76.06 \pm 9.75$ & $69.29 \pm 8.47$ & $<0.01$ \\
\hline Aortic augmentation pressure (mmHg) & $6.42 \pm 4.9$ & $1.61 \pm 4.84$ & $<0.01$ \\
\hline \multicolumn{4}{|l|}{ Neck } \\
\hline C-F PWV (cm/s) & $857.52 \pm 216.18$ & $708.89 \pm 419.42$ & $<0.01$ \\
\hline \multicolumn{4}{|l|}{ Arm } \\
\hline baPWV $(\mathrm{cm} / \mathrm{s})$ & $1314.85 \pm 268.48$ & $1070.42 \pm 190.73$ & $<0.01$ \\
\hline Brachial ASI (mmHg) & $25.8 \pm 8.07$ & $22.67 \pm 6.52$ & $<0.01$ \\
\hline \multicolumn{4}{|l|}{ Leg } \\
\hline Ankle ASI (mmHg) & $34.34 \pm 8.49$ & $30.55 \pm 8.42$ & $<0.05$ \\
\hline \multicolumn{4}{|l|}{ Leg-to-hand pressure ratio } \\
\hline $\mathrm{ABI}$ & $1.12 \pm 0.1$ & $1.09 \pm 0.1$ & $<0.05$ \\
\hline
\end{tabular}

*NS-Not significant, SD: Standard deviation, SBP: Systolic blood pressure, ABI: Ankle-brachial index, ASI: Arterial stiffness index, baPWV: Carotid-femoral pulse wave velocity, DBP: Diastolic blood pressure

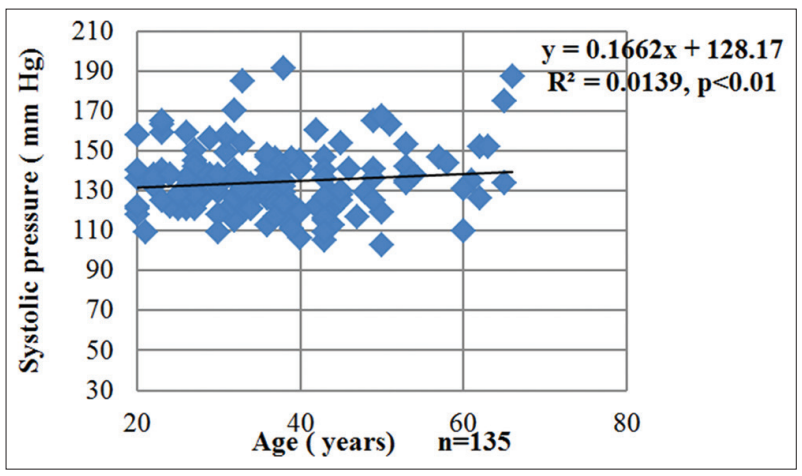

Fig. 1: Linear regression analysis of age versus systolic blood pressure $(\mathrm{mmHg})$ in normal men

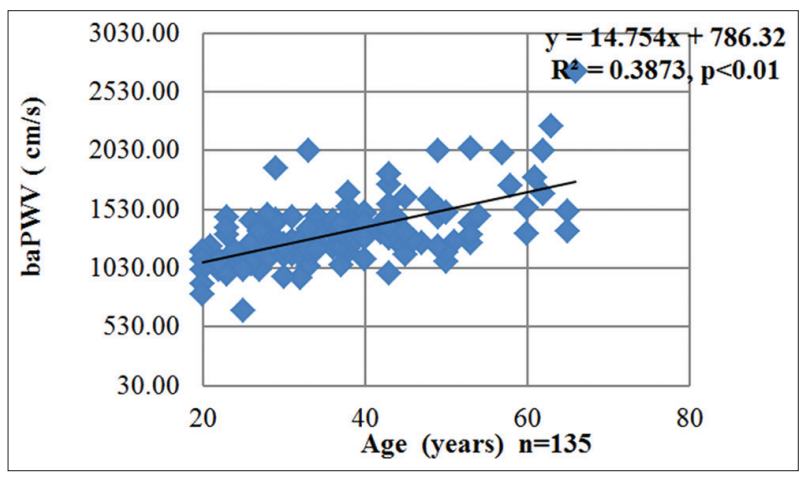

Fig. 2: Linear regression analysis of age versus brachial pulse wave velocity $(\mathrm{cm} / \mathrm{s})$ in normal men

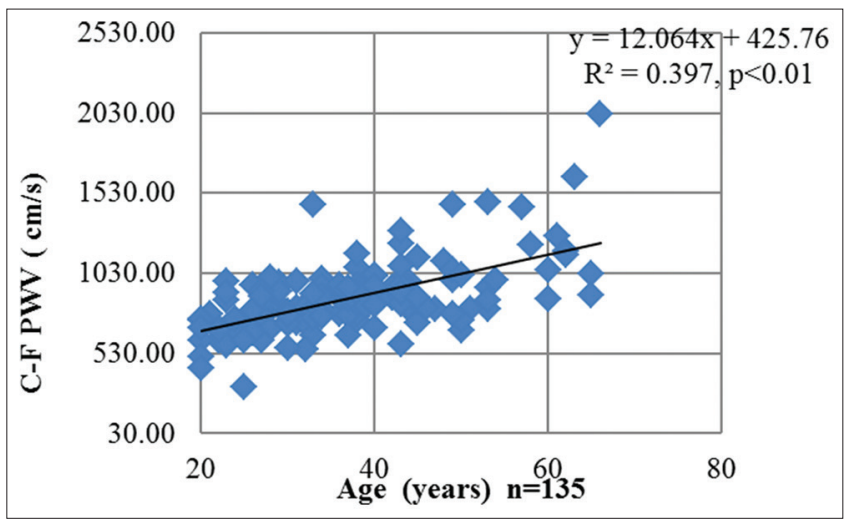

Fig. 3: Linear regression analysis of age versus carotid-femoral pulse wave velocity $(\mathrm{cm} / \mathrm{s})$ in normal men

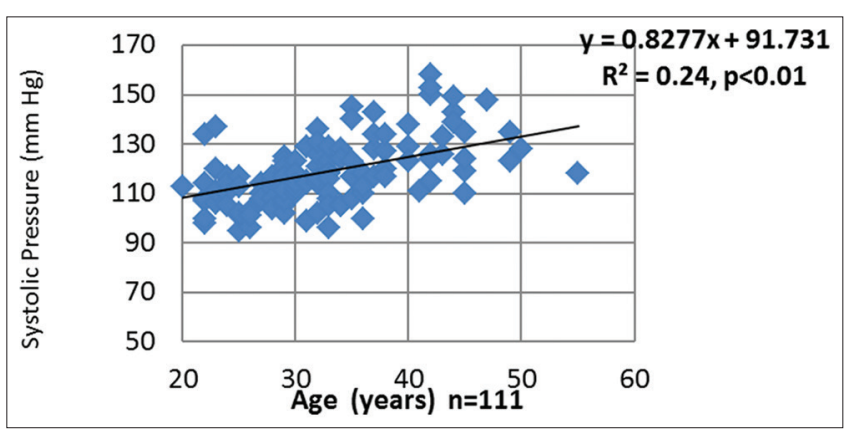

Fig. 4: Linear regression analysis of age versus systolic blood pressure ( $\mathrm{mmHg}$ ) in normal women 
In older aged men (tertile-III), the mean value of pulse pressure was significantly $(\mathrm{p}<0.01)$ less than those in young men (tertile-I), whereas the mean values of the variables concerned, the calculated percentage increment was greatest for C-F PWV with $40 \%[(1032.45-730.06 / 730.06) \times 100]$.

iii. Between Tertiles II and III

In middle-aged men (tertile-II), in the mean values of the variables concerned, the calculated percentage decrement was greatest for baPWV with $17 \%[(1032.45-881.44 / 881.44) \times 100]$.

\section{Healthy women}

The healthy young women (tertile-I) were compared with tertiles II and III as shown in Table 7.

i. With tertile-I

In middle-aged women (tertile-II), in the mean values of the variables concerned, the calculated percentage increment was greatest for baPWV with $12 \%[(1068.17-948.48 / 948.48) \times 100]$.

ii. With tertile-III

In older-age women (tertile-III), in the mean values of the variables concerned, the percentage increment was greatest for baPWV with 25\% $[(1192.15-948.48 / 948.48) \times 100]$.

iii. Between tertiles II and III

In middle-aged women (tertile-II), in the mean values of the variables concerned, the calculated percentage decrement was greatest for aortic augmentation pressure with $76 \%[(3.3-0.76 / 0.76) \times 100]$.

\section{Comparison of hypertensive patients with normal controls}

Mechanical blood flow variables measured using periScope device in known hypertensive patients and normal age- and sex-matched controls are shown in Table 8. It was found that, in known hypertensive patients (Group-I), the mean value of aortic augmentation pressure was highest with 63\% increment in Group-I when compared to Group-II.

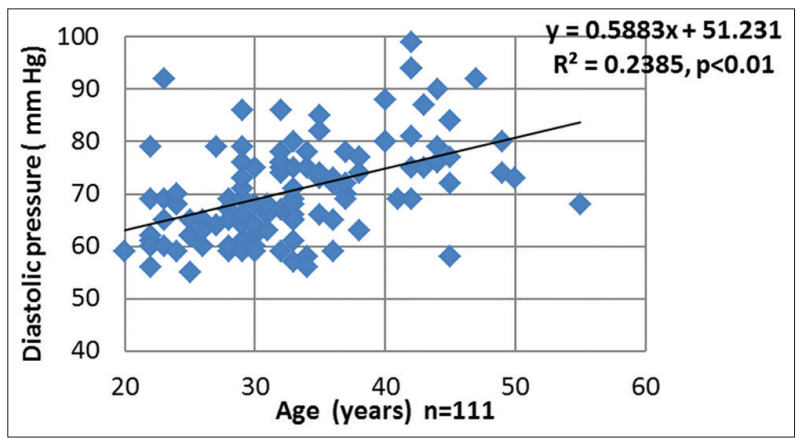

Fig. 5: Linear regression analysis of age versus diastolic blood pressure $(\mathrm{mmHg})$ in normal women

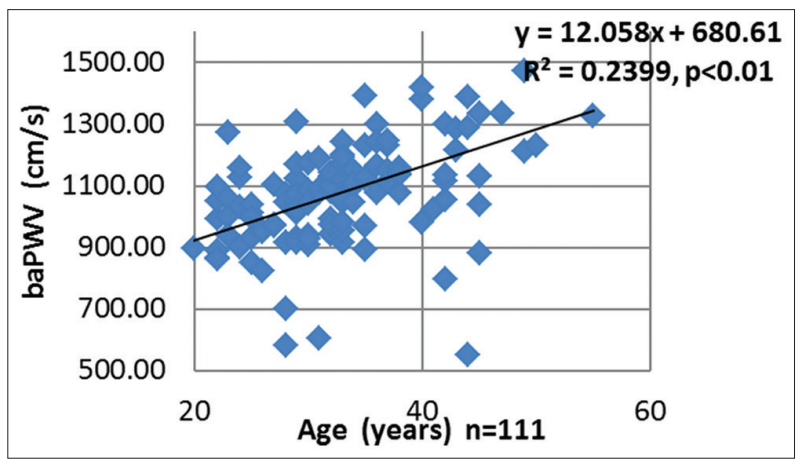

Fig. 6: Linear regression analysis of age versus brachial pulse wave velocity $(\mathrm{mmHg})$ in normal women
Hypertensive threshold values

Using the baPWV and C-F PWV data (Table 8), a threshold for hypertension was arbitrarily defined as the $90^{\text {th }}$ percentile for hypertensive patients. For both men and women, the determined threshold values of baPWV $(\mathrm{cm} / \mathrm{s})$ and C-F PWV $(\mathrm{cm} / \mathrm{s})$ for hypertension were $1738 \mathrm{~cm} / \mathrm{s}(1332.33-[270.39 \times 1.5])$ and $1215 \mathrm{~cm} / \mathrm{s}$ (876.9-[225.33×1.5]), respectively. In one Indian study (Yashmaina et al., 2007) [5], the published threshold values of baPWV $(\mathrm{cm} / \mathrm{s})$ and C-F PWV (cm/s) for hypertension were $>1400 \mathrm{~cm} / \mathrm{s}$ and $>900 \mathrm{~cm} / \mathrm{s}$, respectively, whereas, in one Korean study (Kim et al., 2005), the same were $>1600 \mathrm{~cm} / \mathrm{s}$ and $>1300 \mathrm{~cm} / \mathrm{s}$, respectively [7].

\section{Normal controls}

Using the calculated threshold when the estimated hypertension threshold value of baPWV $(\mathrm{cm} / \mathrm{s})$ was used in normal men and women (study-I/Groups-I and II), it was found that $8 \%$ of men $[(11 / 135) \times 100]$ and $0.9 \%$ of women $[(1 / 111) \times 100]$ were above this threshold. When the estimated hypertension threshold value of C-FPWV (cm/s) was used in normal men and women, it was found that $5 \%$ of men $[(7 / 135) \times 100]$ and $1.8 \%$ of women $[(2 / 111) \times 100]$ were above this threshold. When the estimated hypertension threshold value of both baPWV $(\mathrm{cm} / \mathrm{s})$ and C-FPWV $(\mathrm{cm} / \mathrm{s})$ was used in normal men, $5 \%$ of them were found to have increased risk for high blood pressure. When the calculated hypertension threshold value of both baPWV $(\mathrm{cm} / \mathrm{s})$ and C-FPWV $(\mathrm{cm} / \mathrm{s})$ was used in normal women, none of them was found to have increased risk for hypertension.

Using the threshold value suggested by Yashmaina et al., for baPWV $(\mathrm{cm} / \mathrm{s})$ in healthy men and women (Study-I/Groups-I and II), it was found that $31 \%$ of men $[(42 / 135) \times 100]$ and $2.7 \%$ of women $[(37 / 111) \times 100]$ were above this threshold. When the hypertension threshold value as specified by Yashmaina et al. was used for C-F PWV $(\mathrm{cm} / \mathrm{s})$ in normal men and women, it was found that $37 \%$ of men $[(507 / 135) \times 100]$ and $7.2 \%$ of women $[(8 / 111) \times 100]$ were above this threshold. When the hypertension threshold value as specified by Yashmaina et al. was used for both baPWV $(\mathrm{cm} / \mathrm{s})$ and C-FPWV $(\mathrm{cm} / \mathrm{s})$ in normal men and women, it was found that $17 \%$ of men $[(23 / 135) \times 100]$

Table 4: Normal men Group-I subdivision

\begin{tabular}{lll}
\hline Tertile & $\begin{array}{l}\text { Age range } \\
\text { (years) }\end{array}$ & Group-I: Normal men \\
\hline $\begin{array}{l}\text { Tertile-I } \\
\text { (young age) }\end{array}$ & $18-30$ & $\mathrm{n}=49$, mean \pm SD age $=24.4 \pm 3.8$ years \\
$\begin{array}{l}\text { Tertile-II } \\
\text { (middle age) }\end{array}$ & $31-43$ & $\mathrm{n}=61$, mean \pm SD age $=37 \pm 3.8$ years \\
$\begin{array}{l}\text { Tertile-III } \\
\text { (older age) }\end{array}$ & $\begin{array}{l}\text { Greater } \\
\text { than } 43\end{array}$ & $\mathrm{n}=25$, mean $\pm S D$ age $=52.8 \pm 7.5$ years \\
\hline
\end{tabular}

SD: Standard deviation

Table 5: Normal women Group-II subdivision

\begin{tabular}{lll}
\hline Tertile & $\begin{array}{l}\text { Age range } \\
\text { (years) }\end{array}$ & Group-I: Normal men \\
\hline $\begin{array}{l}\text { Tertile-I } \\
\text { young age) }\end{array}$ & $18-29$ & $\mathrm{n}=33$, mean \pm SD age $=23.9 \pm 2.9$ years \\
$\begin{array}{l}\text { Tertile-II } \\
\text { (middle age) }\end{array}$ & $29-35$ & $\mathrm{n}=42$, mean \pm SD age $=31.6 \pm 2.0$ years \\
$\begin{array}{l}\text { Tertile-III } \\
\text { (older age) }\end{array}$ & $<35$ & $\mathrm{n}=36$ mean \pm SD age $=41.8 \pm 4.6$ years \\
\hline
\end{tabular}

SD: Standard deviation 
Table 6: Comparison of mechanical blood flow variables in normal men based on age versus SBP using Tukey's post hoc analysis

\begin{tabular}{|c|c|c|c|c|c|c|}
\hline \multicolumn{7}{|c|}{ Study-I: Group I: Normal men ( $n=135$, mean $\pm S D$ age $=36.0 \pm 11.3$ years $)$} \\
\hline \multirow[t]{2}{*}{ Variables } & \multirow{2}{*}{$\begin{array}{l}\text { Tertile-I: Young age } \\
18-30 \text { years }(n=49, \\
\text { mean } \pm S D=24.4 \pm 3.8 \text { years })\end{array}$} & \multirow{2}{*}{$\begin{array}{l}\text { Tertile-II: Middle age } \\
31-43 \text { years }(n=61 \text {, } \\
\text { mean } \pm S D=37.0 \pm 3.8 \text { years })\end{array}$} & \multirow{2}{*}{$\begin{array}{l}\text { Tertile-III: Older } \\
\text { age }>43 \text { years }(n=25 \text {, } \\
\text { mean } \pm S D=52.8 \pm 7.5 \text { years })\end{array}$} & \multicolumn{3}{|c|}{$\begin{array}{l}\text { Statistical significance } \\
\text { (p-value) }\end{array}$} \\
\hline & & & & $\begin{array}{l}\text { Tertile I } \\
\text { versus II }\end{array}$ & $\begin{array}{l}\text { Tertile I } \\
\text { versus III }\end{array}$ & $\begin{array}{l}\text { Tertile II } \\
\text { versus III }\end{array}$ \\
\hline \multicolumn{7}{|l|}{ Demographic variables } \\
\hline Body weight (kg) & $69.23 \pm 13.04$ & $70.22 \pm 12.95$ & $73.83 \pm 10.6$ & NS & NS & NS \\
\hline Body height (m) & $1.7 \pm 0.08$ & $1.67 \pm 0.07$ & $1.7 \pm 0.07$ & $<0.05$ & $<0.05$ & NS \\
\hline BMI $\left(\mathrm{kg} / \mathrm{m}^{2}\right)$ & $23.93 \pm 4.39$ & $25.18 \pm 4.02$ & $25.67 \pm 3.3$ & $<0.05$ & NS & NS \\
\hline \multirow{2}{*}{\multicolumn{7}{|c|}{$\begin{array}{l}\text { Mechanical variables of } \\
\text { blood flow (periScope) } \\
\text { a. Directly measured }\end{array}$}} \\
\hline & & & & & & \\
\hline Heart rate (bpm) & $76.44 \pm 11.08$ & $78.55 \pm 12.7$ & $73.83 \pm 12.9$ & $<0.05$ & NS & NS \\
\hline $\mathrm{SBP}(\mathrm{mm} \mathrm{Hg})$ & $133.62 \pm 13.44$ & $131.31 \pm 16.04$ & $138.52 \pm 20.22$ & $<0.05$ & $<0.05$ & $<0.05$ \\
\hline DBP (mmHg) & $72.71 \pm 8.71$ & $77.83 \pm 10.47$ & $79.9 \pm 11.54$ & $<0.01$ & $<0.01$ & NS \\
\hline $\begin{array}{l}\text { Pulse } \\
\text { pressure }(\mathrm{mmHg})\end{array}$ & $61.21 \pm 9.33$ & $53.55 \pm 9.76$ & $58.62 \pm 12.39$ & $<0.001$ & $<0.001$ & $<0.05$ \\
\hline \multicolumn{7}{|l|}{$\begin{array}{l}\text { b. Indirectly derived } \\
\text { Derived pressure }\end{array}$} \\
\hline Aortic SBP (mm Hg) & $110.31 \pm 12.38$ & $111.75 \pm 14.69$ & $120.86 \pm 21.71$ & NS & NS & $<0.05$ \\
\hline $\begin{array}{l}\text { Aortic pulse } \\
\text { pressure }(\mathrm{mmHg})\end{array}$ & $37.04 \pm 6.79$ & $34.4 \pm 7.23$ & $40.24 \pm 12.34$ & $<0.05$ & $<0.05$ & $<0.05$ \\
\hline Aortic DBP (mmHg) & $72.83 \pm 8.24$ & $76.82 \pm 9.57$ & $80.17 \pm 10.98$ & $<0.05$ & $<0.05$ & NS \\
\hline $\begin{array}{l}\text { Aortic augmentation } \\
\text { pressure }(\mathrm{mmHg})\end{array}$ & $5.12 \pm 3.76$ & $6 \pm 3.57$ & $9.69 \pm 7.39$ & NS & NS & $<0.05$ \\
\hline \multicolumn{7}{|l|}{ Neck } \\
\hline C-F PWV (cm/s) & $730.06 \pm 142.6$ & $881.44 \pm 146.59$ & $1032.45 \pm 304.4$ & $<0.001$ & $<0.001$ & $<0.05$ \\
\hline \multicolumn{7}{|l|}{ Arm } \\
\hline baPWV (cm/s) & $1165.62 \pm 195.9$ & $1337.78 \pm 175.9$ & $1531.07 \pm 376.34$ & $<0.001$ & $<0.001$ & $<0.05$ \\
\hline Brachial ASI (mm Hg) & $26.88 \pm 5.55$ & $21.69 \pm 3.05$ & $23.71 \pm 9.27$ & $<0.001$ & NS & $<0.05$ \\
\hline \multicolumn{7}{|c|}{ Leg } \\
\hline Ankle ASI (mm Hg) & $32.34 \pm 7.94$ & $32.6 \pm 6.41$ & $40.13 \pm 10.78$ & NS & $<0.001$ & $<0.05$ \\
\hline \multicolumn{7}{|c|}{$\begin{array}{l}\text { Leg to hand pressure } \\
\text { ratio }\end{array}$} \\
\hline ABI & $1.08 \pm 0.08$ & $1.11 \pm 0.08$ & $1.09 \pm 0.08$ & $<0.01$ & $<0.01$ & NS \\
\hline
\end{tabular}

*NS-Not significant, SD: Standard deviation, SBP: Systolic blood pressure, ABI: Ankle-brachial index, ASI: Arterial stiffness index, C-F PWV: Carotid-femoral pulse wave velocity, DBP: Diastolic blood pressure

and $0.9 \%$ of women $[(1 / 111) \times 100]$ were above this threshold and, therefore, found to have increased risk for hypertension.

Using the threshold as suggested by Kim et al. for baPWV in healthy men and women (Study-I/Group-I\&II), it was found that $10 \%$ of men $[(14 / 135) \times 100]$ and $0.9 \%$ of women $[(71 / 111) \times 100]$ were above this threshold. When the estimated hypertension threshold value as specified by Kim et al. was used for C-F PWV (cm/s) in healthy men and women, it was found that $3.7 \%$ of men $[(5 / 135) \times 100]$ and $1.8 \%$ of women $(2 \%)$ were above this threshold. When the hypertension threshold value as specified by Kim et al. of both baPWV $(\mathrm{cm} / \mathrm{s})$ and C-FPWV $(\mathrm{cm} / \mathrm{s})$ was used in healthy men, $2.2 \%[(3 / 135) \times 100]$ of them were found to have increased risk for high blood pressure. When the calculated hypertension threshold value of both baPWV $(\mathrm{cm} / \mathrm{s})$ and C-F PWV (cm/s) was used in healthy women, none of them were found to have increased risk for hypertension. Figs. 7 and 8 show the distribution of the total population in the different threshold for brachial and C-F PWV.

\section{DISCUSSIONS}

Nicole et al. in their cohort study for a population of 4024 participants measured the arterial stiffness variables from the right side only to save time as the right and left side arterial stiffness variables were correlated [8]. In our study, it was found that, in healthy men and women, the measured baPWV, brachial ASI, ankle ASI, and ABI showed no significant statistical difference between the left and right sides.

Shanker et al. studied the relation of carotid IMT with mechanical variables of blood flow. In the study population of 710 participants, both carotid IMT and mechanical blood flow variables were measured. It was reported that arterial stiffness variables were higher in men than in women. Also as reported by Lama et al., male gender was one of the factors for uncontrolled BP [9]. In our study, it was found that the mean values of SBP and pulse pressure were higher in normal men by $12 \%$ and $18 \%$, respectively, when compared to those values in healthy women. Hence, all the derived variables from the pressure pulse waveform such as PWV, ASI, ABI, and aortic pressure showed a statistically significant higher value in men than women. Of these variables, the percentage increment was greatest for aortic augmentation pressure with $74 \%$ $[(6.42-1.61 / 6.42) \times 100]$.

According to the Guidelines for Assessment of CVD in asymptomatic adults released by the American College of Cardiology (2009), advancing age is one of the non-modifiable risk factors. The deterioration in the vessel elasticity with advancing age is reported in numerous studies. Rogers et al. studied the patient's age-associated changes in PWV, measured by the MRI-based method. It was concluded that, with increasing age, the arterial stiffness increases [10]. In a health survey conducted by Koivistoinen et al., in 1754 participants, there was an increase in vessel stiffness variables with advancing age [11]. A similar trend was observed in our study. In the men population, though the SBP decreases from tertiles I to II (1.5\%), it increases in the tertiles II- 
Table 7: Comparison of mechanical blood flow variables in normal women based on age versus SBP using Tukey's post hoc analysis

\begin{tabular}{|c|c|c|c|c|c|c|}
\hline \multicolumn{7}{|c|}{ Study I: Group II: Normal women $(n=111$, mean \pm SD age $=32.4 \pm 7.5$ years $)$} \\
\hline \multirow[t]{2}{*}{ Variables } & \multirow{2}{*}{$\begin{array}{l}\text { Tertile-I: Young } \\
\text { age, } 18-29 \text { years, } \\
(n=33, \text { mean } \pm S D \\
\text { age }=23.97 \pm 2.86 \text { years) }\end{array}$} & \multirow{2}{*}{$\begin{array}{l}\text { Tertile-II: Middle } \\
\text { age } 29-35 \text { years, } \\
(n=42, \text { mean } \pm S D \\
\text { age }=31.6 \pm 2.04 \text { years) }\end{array}$} & \multirow{2}{*}{$\begin{array}{l}\text { Tertile-III: Older } \\
\text { age }>35 \text { years } \\
(n=36, \text { mean } \pm \text { SD } \\
\text { age }=41.81 \pm 4.6 \text { years })\end{array}$} & \multicolumn{3}{|c|}{$\begin{array}{l}\text { Statistical significance } \\
\text { (p value) }\end{array}$} \\
\hline & & & & $\begin{array}{l}\text { Tertile I } \\
\text { versus II }\end{array}$ & $\begin{array}{l}\text { Tertile I } \\
\text { versus III }\end{array}$ & $\begin{array}{c}\text { Tertile II } \\
\text { versus III }\end{array}$ \\
\hline \multicolumn{7}{|l|}{ Demographic details } \\
\hline Body weight (kg) & $58.69 \pm 12.69$ & $64.73 \pm 12.31$ & $69.14 \pm 12.32$ & $<0.05$ & NS & $<0.05$ \\
\hline Body height (m) & $1.59 \pm 0.07$ & $1.56 \pm 0.06$ & $1.56 \pm 0.06$ & NS & NS & NS \\
\hline $\operatorname{BMI}\left(\mathrm{kg} / \mathrm{m}^{2}\right)$ & $23.16 \pm 3.85$ & $26.52 \pm 5.2$ & $28.27 \pm 4.77$ & $<0.05$ & NS & $<0.05$ \\
\hline $\begin{array}{l}\text { Mechanical variables of } \\
\text { blood flow (periScope) }\end{array}$ & & & & & & \\
\hline a. Directly measured & $75.71+10.36$ & $7631+83$ & $8111+881$ & NS & $<005$ & $<005$ \\
\hline $\begin{array}{l}\text { Heart rate (bpm) } \\
\text { SBP (mm Hg) }\end{array}$ & $111.4 \pm 10.44$ & $116.43 \pm 10.11$ & $\begin{array}{l}81.11 \pm 8.81 \\
128.28 \pm 13.64\end{array}$ & $<0.05$ & $\begin{array}{l}<0.05 \\
<0.001\end{array}$ & $\begin{array}{l}<0.05 \\
<0.001\end{array}$ \\
\hline $\mathrm{DBP}(\mathrm{mm} \mathrm{Hg})$ & $65.11 \pm 7.2$ & $69.18 \pm 7.78$ & $76.75 \pm 9.64$ & $<0.05$ & $<0.001$ & $<0.001$ \\
\hline Pulse pressure (mm Hg) & $46.69 \pm 7.9$ & $47.14 \pm 8.73$ & $51.56 \pm 8.16$ & $<0.05$ & $<0.05$ & $<0.05$ \\
\hline Aortic SBP (mm Hg) & $89.86 \pm 11.87$ & $94.37 \pm 9.71$ & $104.73 \pm 9.69$ & NS & NS & NS \\
\hline $\begin{array}{l}\text { Aortic pulse } \\
\text { pressure (mm Hg) }\end{array}$ & $24.6 \pm 8.91$ & $25.75 \pm 6.45$ & $30.53 \pm 5.72$ & NS & NS & NS \\
\hline Aortic DBP (mm Hg) & $64.89 \pm 6.39$ & $68.08 \pm 7.11$ & $73.77 \pm 6.5$ & NS & NS & NS \\
\hline $\begin{array}{l}\text { Aortic augmentation } \\
\text { pressure }(\mathrm{mm} \mathrm{Hg})\end{array}$ & $0.6 \pm 7.29$ & $0.76 \pm 2.63$ & $3.3 \pm 2.88$ & NS & $<0.001$ & $<0.001$ \\
\hline \multicolumn{7}{|l|}{ Arm } \\
\hline baPWV $(\mathrm{cm} / \mathrm{s})$ & $948.48 \pm 155.78$ & $1068.17 \pm 125.83$ & $1192.15 \pm 222.37$ & $<0.001$ & $<0.05$ & $<0.001$ \\
\hline Brachial ASI (mm Hg) & $19.46 \pm 6.98$ & $21.79 \pm 8.8$ & $23.06 \pm 5.93$ & NS & $<0.05$ & NS \\
\hline \multicolumn{7}{|l|}{ Neck } \\
\hline C-F PWV $(\mathrm{cm} / \mathrm{s})$ & $988.48 \pm 155.78$ & $1038.17 \pm 125.83$ & $1180.15 \pm 222.37$ & $<0.001$ & $<0.05$ & $<0.001$ \\
\hline Leg & & & & & & \\
\hline $\begin{array}{l}\text { Ankle ASI (mm Hg) } \\
\text { Leg to hand pressure } \\
\text { ratio }\end{array}$ & $28.48 \pm 7.36$ & $28.3 \pm 8.39$ & $35.62 \pm 7.34$ & NS & $<0.001$ & $<0.001$ \\
\hline $\mathrm{ABI}$ & $1.07 \pm 0.09$ & $1.07 \pm 0.1$ & $1.1 \pm 0.09$ & NS & $<0.001$ & $<0.05$ \\
\hline
\end{tabular}

* NS-Not significant, SD: Standard deviation, SBP: Systolic blood pressure, ABI: Ankle-brachial index, ASI: Arterial stiffness index, baPWV: Brachial pulse wave velocity, DBP: Diastolic blood pressure

Table 8: Statistical comparison of known hypertensive patients and normal controls

\begin{tabular}{|c|c|c|c|c|c|c|c|}
\hline Variable & \multicolumn{3}{|c|}{$\begin{array}{l}\text { Group I: Known hypertensive }(n=14 \text {, } \\
\text { male/women }=9 / 5 \text {, mean } \pm S D \\
\text { age }=39.3 \pm 10.5 \text { years })\end{array}$} & \multicolumn{3}{|c|}{$\begin{array}{l}\text { Group II: Age- and sex-matched } \\
\text { controls }(n=14, \text { men } / \text { women }=9 / 5 \text {, } \\
\text { mean } \pm S D \text { age }=39.7 \pm 12.2 \text { years })\end{array}$} & $\begin{array}{l}\text { Statistical } \\
\text { significance } \\
\text { (p-value) }\end{array}$ \\
\hline \multicolumn{8}{|l|}{ Demographic details } \\
\hline Body weight (Kg) & 52 & 93 & $74.07 \pm 12.72$ & 50 & 93 & $67.43 \pm 11.82$ & NS \\
\hline Body height $(\mathrm{cm})$ & 152 & 176 & $166.29 \pm 8.1$ & 151 & 174 & $161.07 \pm 7.88$ & NS \\
\hline \multicolumn{8}{|l|}{$\begin{array}{l}\text { Mechanical variables of blood } \\
\text { flow (periScope) }\end{array}$} \\
\hline \multicolumn{8}{|l|}{ a. Directly measured } \\
\hline Heart rate (bpm) & 59 & 89 & $77.7 \pm 9.09$ & 60 & 92 & $72.14 \pm 8.62$ & NS \\
\hline $\mathrm{SBP}(\mathrm{mmHg})$ & 128 & 158 & $140.29 \pm 10.05$ & 103 & 138 & $118.64 \pm 9.54$ & $<0.01$ \\
\hline DBP (mmHg) & 61 & 114 & $81.71 \pm 13.94$ & 59 & 75 & $68.14 \pm 5.81$ & $<0.05$ \\
\hline Pulse pressure (mmHg) & 43 & 70 & $58.5714 \pm 9.24$ & 37 & 68 & $50.78 \pm 8.94$ & $<0.05$ \\
\hline \multicolumn{8}{|l|}{ b. Indirectly derived } \\
\hline \multicolumn{8}{|l|}{ Derived pressure } \\
\hline Aortic DBP (mmHg) & 62 & 108 & $81.35 \pm 11.3$ & 60 & 74 & $68.35 \pm 4.79$ & $<0.05$ \\
\hline Aortic Aug pressure (mmHg) & -2 & 18 & $7 \pm 4.54$ & -3 & 15 & $2.57 \pm 4.39$ & $<0.05$ \\
\hline \multicolumn{8}{|l|}{ Arm } \\
\hline baPWV (cm/s) & 945.35 & 2010.4 & $1332.33 \pm 270.39$ & 857.7 & 1406.55 & $1069.91 \pm 157.5$ & $<0.05$ \\
\hline Brachial ASI (mmHg) & 15.4 & 38.1 & $26.05 \pm 6.26$ & 14.9 & 30.4 & $23.73 \pm 5.07$ & NS \\
\hline \multicolumn{8}{|l|}{ Neck } \\
\hline C-F PWV (cm/s) & 554.4 & 1441.9 & $876.9 \pm 225.33$ & 481.4 & 938.7 & $658.22 \pm 131.24$ & $<0.05$ \\
\hline \multicolumn{8}{|l|}{ Leg } \\
\hline Ankle ASI (mmHg) & 22.6 & 43.8 & $35.43 \pm 6.32$ & 21.5 & 41.4 & $32.50 \pm 4.85$ & NS \\
\hline \multicolumn{8}{|l|}{ Leg to hand ratio } \\
\hline ABI & 0.61 & 1.23 & $1.09 \pm 0.16$ & 0.96 & 1.24 & $1.13 \pm 0.07$ & NS \\
\hline
\end{tabular}

*NS-Not significant, SD: Standard deviation, SBP: Systolic blood pressure, ABI: Ankle-brachial index, ASI: Arterial stiffness index, C-F PWV: Carotid-femoral pulse wave velocity, DBP: Diastolic blood pressure 


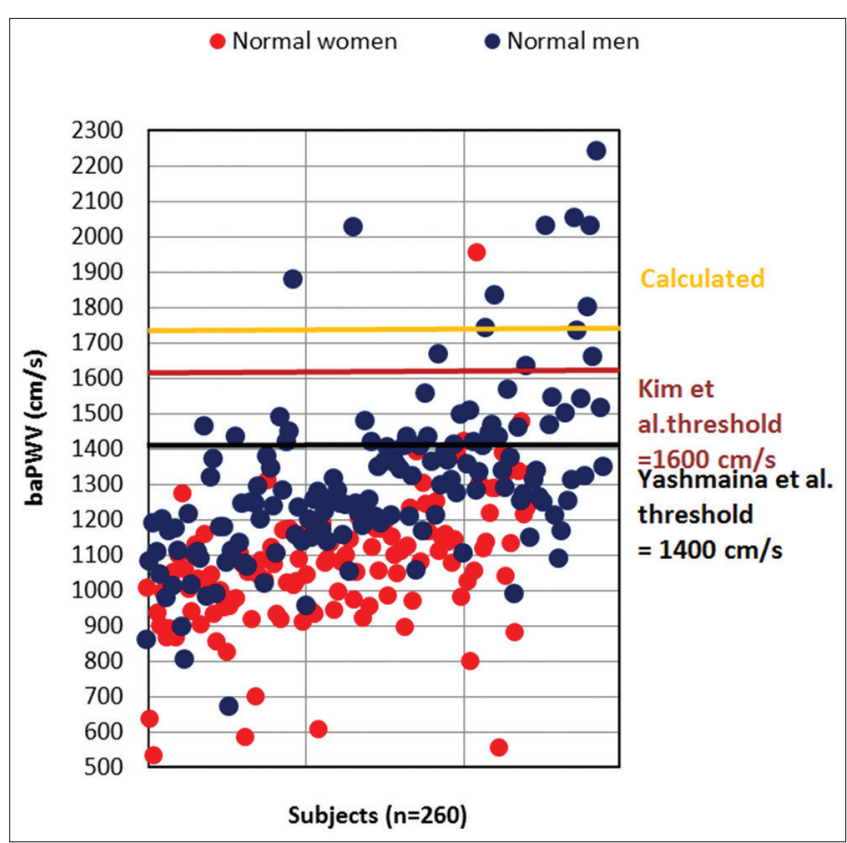

Fig. 7: Distribution of brachial pulse wave velocity according to the various threshold values in known hypertensive patients and normal controls (Study-I and II, Group-I and II)

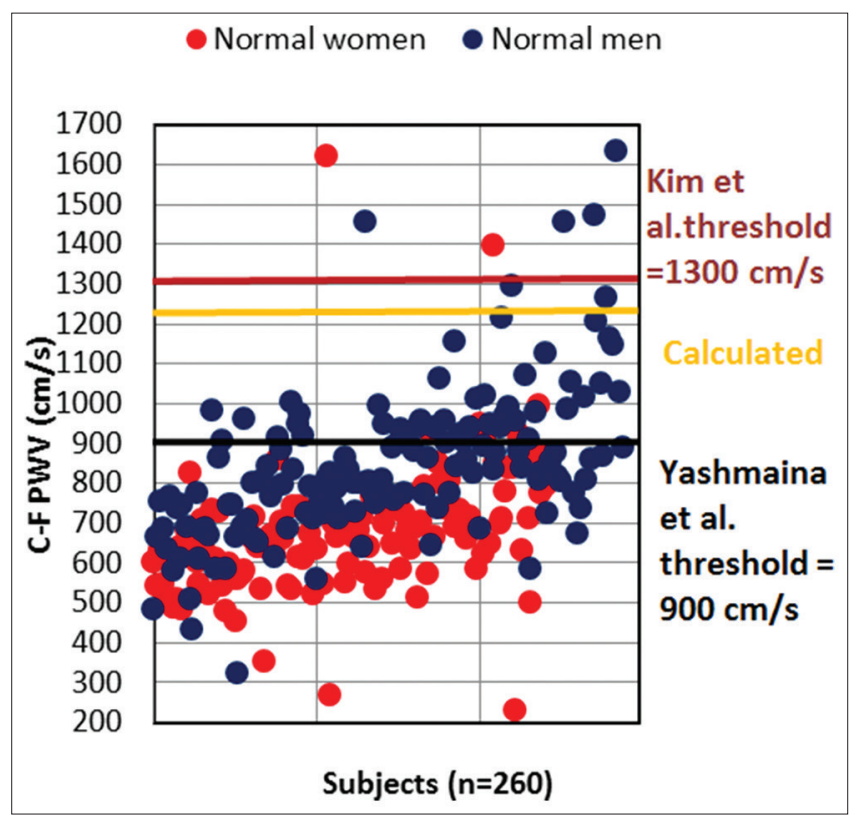

Fig. 8: Distribution of carotid-femoral pulse wave velocity according to the various threshold values in known hypertensive patients and normal controls

III (3.7\%). For women, there is a steady rise in the SBP, $6 \%$ from tertiles I-II and $12 \%$ from tertiles II to III. Hence, all the derived variables from the pulse pressure, PWV, ASI, and aortic pressure increased with advancing age.

To establish the reference value for European population, Boutouyrie et al. studied the distribution of PWV in 16,867 patients, out of which 11,092 were healthy controls. The mean PWV differed in men and women with $\mathrm{p}<0.001$. The PWV and pulse pressure gradually increased with age $[12,13]$. In our study, the mechanical variables of blood slowly rose from tertiles I to III for women. For men, though tertile II showed a lesser pulse pressure than tertile I, the mean PWV and ASI increased in tertile III. The traditional method of evaluating the hypertension is based on the SBP. With recent advancements, numerous variables such as PWV and ASI also contribute to the early detection of hypertension and thereby predict future CVD events. In the study by Kola et al., the PWV and ASI were higher significantly in hypertensive and chronic hypertensive subjects. The vascular stiffness variables remained higher in hypertensive patients compared to normal controls even after the drug therapy (amlodipine monotherapy along with polytherapy) [14]. In our study, the mean SBP was $13 \%$ more in known hypertensive patients compared to healthy controls. All the derived mechanical variables of blood flow were higher for hypertensive patients, where left baPWV showed $26 \%$ increase in the hypertensive patients when compared to the healthy controls. In conclusion, the mechanical variables of the blood flow can be a reliable tool in the evaluation of CVD. They evaluated the status of the arteries noninvasively. It is gender dependent on men having a higher value that strengthens the fact that male gender is one of the risk factors for CVD

\section{REFERENCES}

1. Suhadi R, Thobari JA, Irawan B, Dwiprahasto I. The blood pressure and therapy expenditure change due to hypertension comorbidity: An analytical prospective study in secondary care hospitals in Jogjakarta Indonesia. Int J Pharm Pharm Sci 2016;8(12):78-83.

2. Payne RA, Wilkinson IB, Webb DJ. Arterial stiffness and hypertension emerging concepts. Hypertension 2010;55(1):9-14.

3. Naidu MU, Reddy BM, Yashmaina S, Patnaik AN, Rani PU. Validity and reproducibility of arterial pulse wave velocity measurement using a new device with oscillometric technique: A pilot study. Biomed Eng Online 2005;4(1):1.

4. Sridhar Y, Naidu MU, Usharani P, Raju YS. Non-invasive evaluation of arterial stiffness in patients with increased risk of cardiovascular morbidity: A cross-sectional study. Indian J Pharmacol 2007;39(6):294.

5. Matsumoto C, Tomiyama H, Yamada J, Yoshida M, Shiina K, Yamashina A. Brachial-ankle pulse wave velocity as a marker of subclinical organ damage in middle-aged patients with hypertension. J Cardiol 2008;51(3):163-70.

6. Lindroth M, Lundqvist R, Lilja M, Eliasson M. Cardiovascular risk factors differ between rural and urban Sweden: The 2009 Northern Sweden MONICA cohort. BMC Public Health 2014;14:825.

7. Kim YK, Kim D. The relation of pulse wave velocity with Framingham risk score and SCORE risk score. Korean Circ J 2005;35(1):22-9.

8. van Popele NM, Grobbee DE, Bots ML, Asmar R, Topouchian J, Reneman RS, et al. Association between arterial stiffness and atherosclerosis: The Rotterdam Study. Stroke 2001;32(2):454-60.

9. Gupta SK, Bodakhe SH. An elevated pulse pressure: A major risk factor for cardiovascular diseases. Asian J Pharm Clin Res 2013;6(5):5-11.

10. Rogers WJ, Hu YL, Coast D, Vido DA, Kramer CM, Pyeritz RE, et al. Age-associated changes in regional aortic pulse wave velocity. J Am Coll Cardiol 2001;38(4):1123-9.

11. Koivistoinen T, Virtanen M, Hutri-Kähönen N, Lehtimäki T, Jula A, Juonala $\mathrm{M}$, et al. Arterial pulse wave velocity in relation to carotid intima-media thickness, brachial flow-mediated dilation and carotid artery distensibility: The cardiovascular risk in young finns study and the health 2000 survey. Atherosclerosis 2012;220(2):387-93.

12. Soubra L, Nureddin H, Omar AG, Saleh M. Factors associated with hypertension prevalence and control among lebanese Type 2 diabetic patients. Int J Pharm Pharm Sci 2016;8(10):153-9.

13. Reference Values for Arterial Stiffness Collaboration. Determinants of pulse wave velocity in healthy people and in the presence of cardiovascular risk factors: Establishing normal and reference values. Eur Heart J 2010;31(19):2338-50.

14. Kola S, George M, Srinivasamurthy SK, Selvarajan S, Tamilarasu K, Swaminathan RP, et al. Assessment of arterial stiffness index in hypertensive patients in relation to their treatment status attending a tertiary care center in South India. Pharmacol Pharm 2014;5:413-8. 